\title{
STRATEGIES OF ECONOMIC NATIONALISM AS AN ALTERNATIVE TO NEOLIBERAL IDEOLOGY
}

\begin{abstract}
The article analyzes the socio-practical potential of economic nationalism as a principal basis of economic strategies for modern developing countries. Based on a systematic analysis of the theoretical underpinnings of leading representatives of economic nationalism (from F. List to E. Reinert), and considering the situation of modern nation states in the context of the COVID-19 pandemic, this article argues that the economic policy of Listanism is the most appropriate for practical implementation within societies that seek to develop their economic potential, rather than secure the status of raw materials in the global economy. This article analyzes the essential features of neoliberal economic policy of the "free market", which at the level of social practice does not confirm its universal status and is arguably detrimental to countries that have not put into effect their productive potential and have not formed a domestic market before opening their economy to free trade.
\end{abstract}

Keywords: economic nationalism, strategy, protectionism, neoliberalism, ideology, economic policy, capital, political economy.

\section{INTRODUCTION}

Economic nationalism as a practically justified strategy was formed in the late nineteenth century and throughout its existence has been subject to ambiguous assessments by both liberal and neoliberal traditions. In today's world, at the level of theoretical analysis, this trend is still quite influential. However, with respect to the particularity of global economic crises, at the level of social practice, the strategy of economic nationalism is gradually being revived and becoming increasingly important. In particular, the United States, the European Union and China have actively used the tools of protectionist economic

\footnotetext{
${ }^{1}$ HlushkoTetiana Doctor of Philosophical Sciences, Docent, Professor of the Department of Philosophy, Naional Pedagogical Dragomanov University, Ukraine, e-mail: tetyana. glushko@gmail.com, ORCID: 0000-0002-8759-7975.

2 KozlovetsMykola Doctor of Philosophical Sciences, Professor, Professor of the Department of Philosophy and Political Science, Zhytomyr Ivan Franko State University, Ukraine, e-mail: mykola.kozlovets@ukr.net (corresponding author), ORCID: 000-0002-5242-912X.
} 
policy in response to the COVID-19 pandemic. (Riecke, 2020). There is also a trend according to which China, Germany and Japan are actively developing strategies to promote domestic industry and invest heavily in this process (Warren, 2019). Thus, the crisis of the globalization project, limited by the ideological doctrine of neoliberalism, finally became apparent in the context of the pandemic, which demonstrated the need for a developed national industrial production in any country. At the previous stage, this was especially felt at the level of the medical sector and the food industry. Under the conditions of closed borders, the inability of countries by means of domestic industrial potential to meet global challenges has demonstrated the socio-practical inexpediency of the reliance exclusively on the „free market”. Respectively, the need to rethink the nature and potential of economic processes in individual states has emerged today as one of the key task of both national and global scale. Thus, the formation of a new manner of economic thinking and the transformation of the ideological foundations of the global economy becomes an undisputed priority today. Considering the circumstances and global trends, economic nationalism is becoming one of the most effective alternative strategies to neoliberalism.

\section{LITERATURE REVIEW}

Over the past two centuries some economists, historians, and philosophers have given attention, though insignificantly, to the strategic dimensions of economic nationalism. And, although the theory of economic nationalism is not well known today, and the mainstream of modern economic worldview is the so-called neoclassical model of economics, socio-practical significance of F. List's legacy is analyzed from time to time by modern scholars. In particular, the Israeli researcher D. Levi-Faur at the end of the last century came to the conclusion that after the end of World War II, economic nationalism acquired the status of a neglected research field (Levi-Faur, 1997). Similarly, the modern Norwegian economist E. Reinert emphasizes the need to reject the orthodoxy of today's economic policy and to restore the ancient economic tradition, which is based on historical experience and which he calls the „Other Canon” (Reinert, 2007). As an alternative canon, the researcher considers those theories of economic development that, in practice, helped modern rich countries to get rich, and then disappeared from all textbooks and from the practical economic policy of developing countries. Addressing the origins of this canon is extremely important to ensure the conditions for the progressive development of all regions of the world. Whereas, blind faith in the free market is unable to provide such conditions. E. Reinert emphasizes that the modern world is so complex that we cannot afford to think non-strategically that is, the systemic and long-term results of our actions should become the main focus of the ruling elites. Therefore, economic science should be as pragmatic as possible and rely on experience, and not on theoretical considerations of the neoliberal doctrine.

And the experience of developed countries shows that at the stage of their development they implemented the strategies of economic nationalism, each of which was a unique, not a universal, copy of the „Procrustean” economy. In addition, an important argument in favor of E. Reinert's position is the fact that the Harvard School of Business to this day continues to use the experimental methodology of economic nationalism, on the basis of which the case-study method arose (Reinert, 2007). That is, economic nationalism is focused on the specifics of the conditions of a particular state and its economic particularity. In fact, the 
uniqueness of economic nationalism lies precisely in the pluralistic approach to economic policy, which is significantly lacking in neoliberal doctrine. Note that the industrially developed ,late capitalism" is characterized by state regulation of not only the economy but also of other spheres of social life.

The creation of development strategies in the modern world is significantly complicated by the „universal” recipes of neoliberal theory, the basic principles of which are included in international economic agreements. It is these principles, from E. Reinert's point of view, that ensure the specialization of third world countries in their poverty. Following F. List and other representatives of economic nationalism (S. Witte, D. Mendeleev, E. Helleiner, D. Frank, D. Levi-Faur, Ha-Joon Chang and others), E. Reinert emphasizes that the main source for enrichment of countries is their industrial complex and new technologies. A country that does not produce final products will get permanently impoverished and no external financial loans will save it from poverty, because the invested capital will simply not create conditions for the development of productive potential.

That is why the transformation of the global economy on the basis of the ideas of F. List, who emphasized the need for equal development of national economies as a necessary condition for the introduction of free trade (List, 1841), in modern conditions is becoming especially relevant. Even K. Schwab in his latest work on the economic consequences of COVID-19 recognizes that in today's world globalization ,has been called in to question and even started to recede" (Schwab, Malleret, 2020). Despite the fact that the founder of the Economic Forum continues to defend the logic of globalization processes, it is important to recognize the existence of this dilemma and strengthen nationalist tendencies in the economic processes of the modern world that increasingly demonstrates elements of the globalization logic of development. In fact, in the new stage of the global economic crisis, complicated by the pandemic, there is a need for really deep strategic transformations and the formation of new approaches to the organization of economic processes. Thus, today, on our own mistakes, we are forced to return to the conclusions formed by F. List back in 1841. The researcher argued that liberal economic policy will only be effective when the economic power of nations is proportionate. Whereas failure to comply with this requirement results in the subordination of the economic potential of nations to that of them, which is characterized by stronger economic development, that is, it contributes to the economic colonization of less developed countries (non-industrialized) by more developed (industrialized) ones. For this very reason, F. List spoke about protectionism as the basis of ,industrial education of nations”.

In addition, the researcher considered protectionism as a social mechanism that has certain limits - it is relevant only until the industry acquires an economic status that will allow it to withstand foreign competition. His views were conditioned by the fact that in the nineteenth century, in the context of trade relations with a more powerful Britain, there was a need to preserve economic independence of Germany. Therefore, in a situation of permanent invasion of the British market, F. List took up the development of an appropriate strategy. Its main goal was to develop a system of economic measures that would create an effective system of interaction with an economically more developed country. The essence of this approach was to preserve its own economic identity by the German state and prevent its transformation into an economic adjunct of the British economic system. Positioning the nation as an economic structure, F. List affirmed that countries achieve economic power and prosperity not because of the doctrine of liberalism, but because of protectionism, and insisted on the distinction between such phenomena as political (national) and cosmopolitan 
(international) economy. Thus, according to F. List, the main task of any nation is the development of its own productive forces, that is to say high-quality industrialization, production of end products but not raw materials for them. The researcher insisted that a free trade system can be introduced only if countries achieve economic parity. In particular, he introduces detailed historical examples when nations lost their independence and even ceased to exist politically mainly because their economic system did not contribute to the development of their statehood (List, 1841). It should be noted that these remarks are quite important in the context of modern Ukraine that has not passed the stage of industrialization in full and currently has a rather difficult situation in the industrial sector of the national economy.

According to the position of the founder of economic nationalism, the economic systems of individual nations have their own structural specificity, which is determined by their history, traditions and legislation. The researcher believed that it would make sense for each country to search for its own "national economy". Therefore, state intervention in the economic life of society is a necessary condition until society reaches a level of economic development that is acceptable for the transformation of a closed economic system into an open one. That is, F. List placed liberal theory in a specific historical and national context, concluding that contrary to the claims of this theory to universality, it is actually not at all as scientific and aseptic as it wants to appear. F. List succeeded to evidentiate that only countries that have taken a dominant position in world competitiveness rankings and need new spaces for economic expansion are interested in liberalization. Instead, the implementation of the concept of national interests and the idea of statehood requires other approaches, namely a strategy that defends the right of the state to represent the interests of society and use national capital for its benefit. Thus, E. Reinert proves that the instrumentarium proposed by F. List has been effectively applied in Japan and South Korea. (Reinert, 2007).

However, in the global context, the concerns of the founder of economic nationalism have gone unnoticed by most politicians and influential economists of the modern world and the neoliberal doctrine of the free market became the basis of the leading scenario of globalization, which has been actively implemented since the 1970s and led to the deepening of economic equality between countries, forming a system of international loans, the basic principles of which do not provide for the implementation of development strategies for the "third world". Thus, studies of modern economists have shown that the more external financial borrowing a country uses, the slower its economy develops (Prasad, Rajan, Subramanian, 2007).

The same point of veiw can be traced in the study of the modern American economist of South Korean descent Ha-Joon Chang, who claims that the principles of neoliberalism the free market and free trade - call for sacrificing equality for the sake of growth, but as a result neither the first nor the second is achieved. (Ha-Joon Chang, 2007). The researcher emphasizes that in the recent twenty-five years since borders got opened and a free market appeared the growth has only slowed down. At the same time, practically all modern countries, including the United Kingdom and the United States, which we now consider to be developing by means of implementing of free trade instruments, have created their capital and national wealth on principles that are completely contrary to the basic postulates of neoliberal economics (Ha-Joon Chang, 2007).

Being a specialist in economic development Ha-Joon Chang places special emphasis on the fact that modern developed countries have often used the tools of economic 
protectionism in the process of development, defending itself from foreign investors, which is completely contrary to the principles of the neoliberal economic doctrine spread by the West. Intruducing specific historical examples, Ha-Joon Chang demonstrates that Great Britain and the United States are not at all the birthplace of free trade. Moreover, for a long time they were the most protectionist countries in the world. While mental models of modern economic behavior in developing countries are ,tailored" under the framework of market relations or so-called ",market totemism” (a term of J. K. Galbraith) as an unalterable, the only „,correct” vision of the essence of economic processes.

The policy of protectionism in the history of developed countries is confirmed in the thorough research of E. Reinert, previously mentioned, emphasizing that rich countries became rich solely through protectionist measures that protected domestic enterprises from foreign competition by imposing quotas and customs tariffs on imported goods. In particular, the researcher gives examples from the United States, Japan and other developed countries (Reinert, 2007). But the specificity of the current situation lies in the fact that today the policy of protectionism is directly prohibited by multilateral economic agreements and outlawed by international financial organizations (Ha-Joon Chang, 2007; Reinert, 2007). This position of the international community of neoliberals is a logical reflection of the negative attitude towards economic strategies of the national direction.

\section{RESULTS AND DISCUSSIONS}

Within the modern Euro-Atlantic tradition, economic nationalism continues to be actively criticized and used to refer to the term "economic populism" (de Bolle, 2019), demonstrating negligence towards this alternative economic strategy In particular, it is emphasized that economic nationalism is a threat to global cooperation and slowdown of global economic growth. A significant number of modern neoliberal researchers position themselves as sharp opponents of economic nationalism strategies. This bunch includes, in particular, such thinkers as K. Schwab, T. Malleret, J.A. Tucker, A. J. Abbas, J. Zrałek, I. Colantone, P. Stanig and others. They see economic nationalism as a temporary product of the crisis of liberalism and democracy. Their criticisms relate primarily to accusation of political populism and the obsolescence of the "ideology" of economic nationalism as the one that takes us back to the 19th century and seems to have completely lost relevance for the modern global world. In particular, A. J. Abbas insists that the policy of economic nationalism, in the absence of strict control, can be quite dangerous, because it always seeks to maximize the wealth of the nation at the expense of other countries and encourages the use of force to achieve national goals.

However, in our opinion, such a danger lies precisely in the case of unilateral application of the policy of economic nationalism by individual countries. This very practice became the basis of neoliberal economic policy. According to the American researcher M. Mann, the United States itself is a nation-state. The researcher appeals to the fact that the value of national trade in the United States has always prevailed over the value of international trade. Their capitalism is much more national than the capitalism of any European country (Mann, 1993).

Thus, such an economic ideology as neoliberalism, in its essence, is also the embodiment of the principles of economic nationalism, but at the global level. Thus, the Canadian researcher E. Helleiner at the beginning of this century highlighted that economic nationalism continues to retain its ideological influence in the context of globalization since 
it can have various manifestations and it is not necessary to pursue a policy of protectionism, because its essence is determined not by form, but by content. Thus, it is not just a policy of protectionism, but an approach that can be linked to a wide range of economic policies, including support for economic liberalization and globalization (Helleiner, 2002). Therefore, it can be embodied in various political projects, including within the framework of liberal economic policy. Another contemporary researcher, R. Mikecz, also demonstrates that economic nationalism and economic liberalism do not always contradict each other, because the economic policy of liberalism can be used to achieve nationally oriented economic goals. In particular, we are talking about the fact that «the self-image of a nation plays a significant role in shaping its economic policies» (Mikecz, 2019). Thus, economic policy is positioned as a product of national identity, testifying to the powerful strategic connection between these elements of public consciousness.

The global protectionism of the Euro-Atlantic economic culture has led to the dominance and assertion of the leading role of the United States in the modern world. The effectiveness of social governance based on the introduction of economic nationalism within the country and the spread of its economic interests at the global level led to extremely rapid growth of the country's economy, especially after World War II. Thus, D. Frank made a rather successful attempt to analyze the political history of American economic nationalism. The author has contributed to the renewal of the debate regarding the opposition between "free market" theory and protectionism. Her work «Buy American: The Untold Story of Economic Nationalism» demonstrates the economic manipulation of public consciousness by individual political parties throughout the history of American statehood (Frank, 2000). E. Reinert also draws attention to the fact that the United States subsidizes and protects many of its industries, from agriculture to high technology (Reinert, 2007). In modern conditions, however, such manipulations go beyond the boundaries of a separate state and in many respects become the basis of a globally oriented socio-economic policy. In particular, the prospects for further development of economic nationalism in the modern United States are actively illustrated by R. Kuttner, pointing to the corresponding program trends in both Trump's policy and J. Biden's future economic program (Kuttner, 2020). Moreover, such modern researchers as I. Colantone and P. Stanig acknowledge that «economic nationalism was already on the rise from the early 1990s, and it has been at the core of euroskeptic campaigns such as Brexit» (Colantone, Stanig, 2019).

In general, modern developed countries have followed somewhat different paths of economic nationalism implementation. Thus, in particular, the United States pursues a trade policy that prioritizes the interests of capital over the interests of workers but Great Britain and Germany have chosen another path: taking an active part in international trade, they also solidly supported their domestic industry and their workers (Warren, 2019). In addition, the American government does not fully comply with the principles of the free market and permanently interferes in the economic process, mainly in order to protect the interests of international corporations. Thus, in the conditions of the modern information age, it is also important to protect the national economic interests of countries and the formation of a self-sufficient economic life worlds.

Recovery and development of domestic industry remains the foundation for the progressive development of the economy and its permanent growth. A country with a feudal mode of production can not profit from interaction with economic systems that technologically dominate it. The expected result of this interaction is economic 
obsolescence and poverty. The lack of a strong industrial sector causes significant depopulation of countries, which we observe in the practical experience of modern Ukraine - the phenomenon of guest workers and the refusal to have children. Whereas, according to E. Reinert, population growth is an important condition for economic growth. Rich countries, where workers from poor countries emigrate to (cheap labor), receive additional economic benefits from this. At the same time, one should not forget that the basis for making a profit is not the invested capital itself but capital combined with labor, that is, the creation of a new product, in terms of Marxism - added value.

In this way, the economic self-sufficiency of countries, that is, their ability to provide themselves with all the necessary funds of the national industrial sector, is becoming a new trend of the XXI century. Consequently, one of the recent key points of economic policy of developed countries has been the protection of their national companies, which they save from being absorbed by foreign investors, aware of the financial losses that will result from the implementation of such undesirable strategies (Macrae, 2020; Riecke, 2020), that have become especially relevant in a pandemic. For this very reason we insist that the formation of an economic strategy that meets the needs and values of a particular society - rather than functionate with abstract ,universal" models - can be formed exclusively within the theoretical limits of economic nationalism. Indeed, it is just the kind of ideological basis that provides for the definition of long-term development goals and consideration of modern environmental and technological trends. In the modern world, it is also worth talking about economic eco-nationalism as a paradigm of social development that entail the introduction of economic strategies with maximum consideration of environmental factors and technological innovations in the production process.

\section{CONCLUSIONS}

As a matter of fact, the essence of economic nationalism is to use all available tools to stimulate the national producer and industry of the country in order to provide opportunities for being competitive in global stage. Thus, the main goal of economic policy should be the investment in national job opportunities and technological renewal of infrastructure. As a consequence, the new economic policy of developing countries should provide for the creation of conditions for the development of small and medium-sized businesses within the country. The economic success of the country is impossible on the basis of neoliberal theory, that is, without an industrial sector and a reliable technological base. Therefore, economic nationalism, as a fundamental strategy of progressive economic development, contributing to the protection of systemically important economic sectors of the state, is not just a historical heritage of economic thought. The policy of economic nationalism in its substantive features should be oriented towards the formation of a steadily running production core and provide society with its own internal ,economic basis”. Consequently, the economic paths of the countries that are moving today along the neoliberal „route" require significant adjustments in the direction of control over the movement of national capital, as well as the approval of a strategic plan for the development of the major branches of domestic industry. It is the remedy for solving these complex problems at the level of socio-economic practice that will determine the place of modern countries on the geo-economic map of the world. Therefore, along with maintaining its political stability, Ukraine must finally move on to solving a key macro-problem - modernization of the 
economy through reindustrialization, aiming to return our country to the world club of industrialized countries.

\section{REFERENCES}

Abbas, A.J. (2017). Economic Nationalism: Philosophical Foundations. "Journal of Competitiveness Studies", Vol. 25. Issue 2.

de Bolle, M. (2019). The Rise of Economic Nationalism Threatens Global Cooperation. Access on the internet: https://www.piie.com/blogs/realtime-economic-issues-watch/rise-economicnationalism-threatens-global-cooperation.

Colantone, I. Stanig, P. (2019). The Surge of Economic Nationalism in Western Europe. “Journal of Economic Perspectives”, Vol. 33, № 4.

Frank, D. (2000). Buy American: The Untold Story of Economic Nationalism. Boston: Beacon Press.

Ha-Joon Chang (2007). Bad Samaritans. Rich Nations, Poor Policies and the Treat to the developing World. London: Random House.

Helleiner, E. (2002). Economic Nationalism as a Challenge to Economic Liberalism? Lessons from the $19^{\text {th }}$ Century. “International Studies Quarterly”. Vol. 46, № 3.

Kuttner, R. (2020). Biden's New Economic Nationalism: Better Than You May Think. Access on the internet: https://prospect.org/api/amp/economy/biden-new-economic-nationalism-betterthan-you-may-think/?_twitter_impression=true

Levi-Faur, D. (1997). Friedrich List and the Political Economy of the Nation-State. "Review of International Political Economy”, Vol.4, № 1.

List, F. (1841). Das Nationale System Der Politischen Ökonomie. Access on the internet: https://eet.pixel-online.org/files/etranslation/original/kreuzgang.org_pdf_friedrich-list.dasnationale-system-der-politischen-oekonomie.pdf

Macrae, T. (2020). Economic Nationalism and Merger Control: Impact of COVID-19. Access on the internet: https://www.competitionpolicyinternational.com/economic-nationalism-andmerger-control-impact-of-covid-19/

Mann, M. (1993) Nation-States in Europe and Other Continents: Diversifying, Developing. "Daedalus", Vol. 122, № 3.

Mikecz, R. (2019). The Cornerstone of Economic Nationalism: National Self-image. Access on the internet: https://link.springer.com/article/10.1007/s40647-019-00271-5.

Reinert, E. (2007). How Rich Countries Got Rich and Why Poor Countries Stay Poor. New York: Hachette Book Group.

Riecke, T. (2020). Covid-19 Causes a New Wave of Economic Nationalism// Access mode: https://merics.org/en/analysis/covid-19-causes-new-wave-economic-nationalism

Prasad, E., Rajan, R., Subramanian, A. (2007). The Paradox of Capital. Access on the internet: https://www.imf.org/external/pubs/ft/fandd/2007/03/prasad.htm.

Schwab, K., Malleret, T. (2020). COVID-19: The Great Reset, Geneva: World Economic Publishing.

Tucker, J.A. (2018). The Modern Origins of Economic Nationalism. Access on the internet: https://www.aier.org/article/the-modern-origins-of-economic-nationalism/.

Warren, E.A. (2019). Plan for Economic Patriotism. Access on the internet: https://medium. com/@teamwarren/a-plan-for-economic-patriotism-13b879f4cfc7. 
Zrałek, J. (2019). The Impact of Economic Nationalism on Investment Arbitration - A Central European Perspective. Access on the internet: https://papers.ssrn.com/sol3/papers. cfm?abstract_id=3573507.

DOI: $10.7862 /$ rz.2020.hss.39

The text was submitted to the editorial office: September 2020.

The text was accepted for publication: December 2020. 
